\title{
HIGH PRESSURE VAPOR-LIQUID-LIQUID EQUILIBRIA FOR THE ETHYLENE-MEK-WATER SYSTEM*
}

\author{
Masahiro YORIZANE, HiroKatsu MASUOKA, Shunsuke IDA** AND TAMotsu IKEDA*** \\ Department of Chemical Engineering, Hiroshima University, Hiroshima
}

For the separation of mixtures numerous separation processes are used in industry, e.g. distillation, extraction, and crystallization. Distillation, however, requires heating of the mixture, which is not suitable for a heat-sensitive mixture. Extraction is effective for such a mixture, but usually requires an auxiliary operation like distillation for the recovery of solvent. The solvent power of compressed gases has been known since the first qualitative observation on the extraction of materials by supercritical gases was made by Hannay ${ }^{3}$ in 1880 .

Although vapor-phase extraction with compressed gas is an attractive separation method, it is only in recent years that interest has revived, and relatively little work has been done on high-pressure vaporliquid equilibria with supercritical gas ${ }^{1,2)}$. The purpose of this work is to obtain phase equilibrium data for the ternary ethylene-methyl ethyl ketone-water system and to examine the solvent effect of ethylene at temperatures near its critical temperature and at high pressures.

\section{Experimental Apparatus and Method}

The method for high pressure vapor-liquid equilibrium determinations has been reviewed in detail by numerous authors ${ }^{4}$. The most common method, referred to as the vapor circulation method, consists of an equilibrium cell and a circulation pump. The experimental apparatus was a modification of that used previously ${ }^{7}$. The equilibrium cell was a transparenttype Jerguson gauge with a stainless steel liquid chamber holding about $90 \mathrm{ml}$.

The samples were analyzed by a Shimadzu GC-1C gas chromatograph in conjunction with an Infotoronics Integrator Model CRS-104. PEG $6000(1.6 \mathrm{~m})$ and Porapack Q $(1.6 \mathrm{~m})$ were used as the column packing materials and hydrogen was used as the carrier gas. Purities of materials used were, for ethylene: $99.95 \mathrm{~mol} \%$, methyl ethyl ketone: $99.6 \mathrm{~mol} \%$,

\footnotetext{
* Received on October 29, 1973

Presented at the 37th Annual Meeting of The Soc. of Chem. Engrs., Japan, April 4, 1972

** Daiseru Limited

*** Teijin Limited

=730 広島市千田町3-8-2

広島大学工学部化学工学科 頼実正弘
}

and water: distilled water.

\section{Results and Discussion}

Vapor-liquid-liquid equilibrium data for the system studied are shown in Table 1. The experiment was done at four isothermal conditions $(10.8,14.8,20.0$ and $25.0^{\circ} \mathrm{C}$ ) and at pressures up to about $50 \mathrm{~atm}$. As equilibrium compositions in vapor were essentially pure ethylene, these are not shown in this table. Concentrations of water in vapor were so small that these were not detected in gas chromatographic analysis. Concentrations of methyl ethyl ketone (MEK) in vapor were at most 1 mole percent, and the higher the temperature and pressure, the lower the concentration of MEK in vapor tended to become. Although MEK is partially miscible with water in the absence of ethylene, the immiscibility was enhanced by increasing system pressure or increasing ethylene solubility.

It has been known that the miscibility gap in liquid-liquid equilibria for the MEK-water system narrows and finally disappears as the pressure is increased isothermally ${ }^{5}$. Liquid-liquid equilibria were also measured for the nitrogen-MEK-water system. Pressures up to $40 \mathrm{~atm}$ did not affect the liquid-liquid equilibrium for the system, because solubility of nitrogen was very small. These results indicate that the width of the miscibility gap in the system with ethylene does not result from mere pressure rise, but results from the solvent effect of ethylene in the liquid phase.

Degree of separation was expressed by the separation factor $\alpha$, defined as

$$
\alpha=\left(x_{M}^{I} / x_{W}^{I}\right) /\left(x_{M}^{I I} / x_{W}^{I I}\right)
$$

where $x_{M}^{I}$ and $x_{W}^{I}$ are the mole fraction of MEK and water in MEK-rich phase and $x_{M}^{I I}$ and $x_{W}^{I I}$ are the mole fraction of MEK and water in water-rich phase (all on an ethylene-free basis). The separation factor of the system is plotted in Fig. $\mathbf{1}$ as a function of pressure. Due to the difficulty of analyzing low concentrations of $x_{M}^{I I}$ and $x_{W}^{I}$, the values of the separation factor fluctuate considerably. The general trend is that the separation factor increases with decreasing temperature and increasing pressure. In other words, 


\begin{tabular}{|c|c|c|c|c|c|c|c|}
\hline \multirow{3}{*}{$\begin{array}{l}\text { Temp. } \\
{\left[{ }^{\circ} \mathrm{C}\right]}\end{array}$} & \multirow{3}{*}{$\begin{array}{l}\text { Pressure } \\
\text { [atm] }\end{array}$} & \multicolumn{4}{|c|}{$\begin{array}{c}\text { Table } 1 \text { Experimental equilibrium data } \\
\text { Composition [Mole percent] }\end{array}$} & & \\
\hline & & \multicolumn{3}{|c|}{ Top liquid layer } & \multicolumn{3}{|c|}{ Bottom liquid layer } \\
\hline & & Ethylene & MEK & Water & Ethylene & MEK & Water \\
\hline 8.0 & 15.0 & 18.36 & 71.50 & 10.14 & 0.22 & 7.05 & 92.73 \\
\hline 10.8 & 10.0 & 13.22 & 70.68 & 16.10 & 0.21 & 7.22 & 92.57 \\
\hline 10.8 & 20.0 & 26.47 & 65.26 & 8.27 & 0.30 & 5.82 & 93.88 \\
\hline 10.8 & 48.5 & 98.10 & 1.90 & 0 & 0.26 & 2.62 & 97.12 \\
\hline 14.8 & 10.0 & 10.46 & 71.94 & 17.60 & 0.20 & 7.87 & 91.93 \\
\hline 14.8 & 20.0 & 23.99 & 66.71 & 9.30 & 0.26 & 6.00 & 93.74 \\
\hline 14.8 & 30.0 & 40.02 & 53.23 & 6.75 & 0.30 & 4.26 & 95.44 \\
\hline 14.8 & 35.0 & 52.52 & 45.14 & 2.34 & 0.21 & 3.72 & 96.07 \\
\hline 14.8 & 40.0 & 62.61 & 35.40 & 1.99 & 0.41 & 3.81 & 95.78 \\
\hline 14.8 & 45.0 & 74.03 & 25.97 & 0 & 0.47 & 3.59 & 95.94 \\
\hline 20.0 & 10.0 & 8.80 & 70.39 & 20.81 & 0.15 & 7.07 & 92.78 \\
\hline 20.0 & 20.0 & 18.72 & 68.38 & 12.90 & 0.21 & 5.92 & 93.87 \\
\hline 20.0 & 30.0 & 36.66 & 56.73 & 6.61 & 0.35 & 4.90 & 94.75 \\
\hline 20.0 & 35.0 & 44.08 & 50.69 & 5.23 & 0.39 & 4.41 & 95.20 \\
\hline 20.0 & 40.0 & 55.78 & 39.69 & 4.53 & 0.38 & 3.98 & 95.64 \\
\hline 20.0 & 45.0 & 52.25 & 44.80 & 2.95 & 0.41 & 3.49 & 96.10 \\
\hline 20.0 & 50.0 & 75.76 & 22.65 & 1.59 & 0.39 & 3.04 & 96.57 \\
\hline 25.0 & 20.0 & 20.16 & 64.63 & 15.21 & 0.27 & 6.13 & 93.60 \\
\hline 25.0 & 35.0 & 36.76 & 54.42 & 8.82 & 0.30 & 4.06 & 95.64 \\
\hline 25.0 & 40.0 & 47.93 & 47.42 & 4.65 & 0.33 & 3.65 & 96.02 \\
\hline 25.0 & 45.0 & 51.97 & 43.86 & 4.17 & 0.33 & 3.62 & 96.05 \\
\hline 25.0 & 51.7 & 71.52 & 26.90 & 1.58 & 0.36 & 3.35 & 96.29 \\
\hline
\end{tabular}

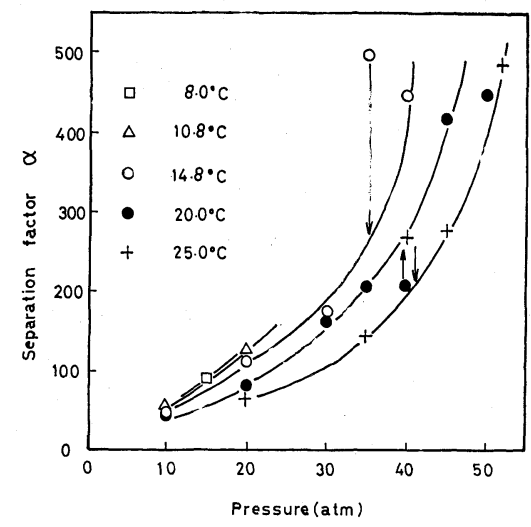

Fig. 1 Separation factor as a function of pressure

lower temperature and higher pressure are desirable for the separation. However, these conditions are limited due to the formation of ethylene hydrate. In Table 2 formation pressures of ethylene hydrate are shown for the ethylene-MEK-water system in the two-liquid region. From these data the formation pressures rise due to the presence of MEK. Hydrate formation is desirable from the standpoint of separation factor. With respect to this, the removal of water from an aqueous solution by hydrate formation is reported in the literature ${ }^{6)}$.

\section{Conclusion}

Vapor-liquid-liquid equilibria for the ethyleneMEK-water and nitrogen-MEK-water system have been described. In the system with nitrogen pressures up to $40 \mathrm{~atm}$ did not affect the liquid-liquid
Table 2 Formation pressure of ethylene hydrate for ethylene-MEK-water system in two-liquid region

\begin{tabular}{cccc} 
Temp. $\left[{ }^{\circ} \mathrm{C}\right]$ & Pres. $[\mathrm{atm}]$ & Temp. $\left[{ }^{\circ} \mathrm{C}\right]$ & Pres. $[\mathrm{atm}]$ \\
\hline 2.5 & 11.60 & 12.0 & 31.00 \\
4.6 & 13.05 & 13.0 & 33.20 \\
6.0 & 15.40 & 14.0 & 38.75 \\
8.1 & 18.85 & 15.0 & 48.50 \\
10.0 & 23.25 & 10.8 & $21.50^{*}$ \\
11.0 & 26.10 & &
\end{tabular}

* This value is in one-liquid region: MEK, $2.35 \mathrm{~mol} \%$, Water, $97.65 \mathrm{~mol} \%$

equilibria. On the other hand, in the system with ethylene the immiscibility in liquid phase was enhanced by increasing pressure and decreasing temperature until an ethylene hydrate was formed. The formation pressures of the ethylene hydrate were aslo reported for the ethylene-MEK-water system in the two-liquid region.

\section{Acknowledgment}

This work was partially supported by Grant-in-Aid for Scientific Research from the Ministry of Education, Japan.

\section{Literature Cited}

1) Elgin, J. C. and J. J. Weinstock: J. Chem. Eng. Data, 4, 3 (1959)

2) Ellis, S. R. M.: Brit. Chem. Eng., 16, 358 (1971)

3) Hannay, J. B.: Proc. Roy. Soc., 178, 30 (1880)

4) Hirata, M. and S. Suda: Kagaku Kōgaku, 28, 397 (1964)

5) Weale, K. E.: "Chemical Reaction at High Pressures", E. and F. N. Spon Limited, London (1966)

6) Werezak, G. N.: Chem. Eng. Progr. Symp. Ser., 65(91), 6 (1969)

7) Yorizane, M., S. Yoshimura and H. Masuoka: Bull. Japan Petrol. Inst., 14, 105 (1972) 